\title{
Pemanfaatan Thermoelectric Generator pada Pembangkit Listrik Tenaga Surya (PLTS)
}

\author{
Sukma Abadi ${ }^{1 *}$, Makmur Saini ${ }^{2}$, Andar Triwijaya, $^{3}$ dan Fina Pratiwi ${ }^{4}$ \\ 1,2,3,4 Jurusan Teknik Mesin, Politeknik Negeri Ujung Pandang, Makassar 90245, Indonesia \\ ${ }^{*}$ sukma.abadi@poliupg.ac.id
}

\begin{abstract}
This study aims to observe the potential utilization of Thermoelectric Generator (TEG) in increasing the output voltage of solar panels. This study also aims to observe the effect of the number of TEG modules used on the magnitude of the total TEG voltage generated. The study was conducted by installing several TEG modules at the bottom of the solar panel module. Seven TEG modules are arranged in series. The voltage produced by solar panels is obtained from the energy of solar radiation, while the voltage from TEG is obtained from solar thermal energy. The combined voltage generated from the solar panel and the voltage from the TEG is called the hybrid solar energy system voltage. From the tests carried out the hybrid system voltage is greater than the voltage of the solar panel, both with 6 TEG and with 7 TEG. In the use of 6 TEGs, there is an additional voltage, which is an average of 0.60 Volts, while with the use of 7 TEGs an average of 0.77 Volts.
\end{abstract}

Keywords: solar panel; thermoelectric generator; hybrid system

\begin{abstract}
Abstrak: Penelitian ini bertujuan untuk mengamati potensi pemanfaatan Thermoelectric Generator (TEG) dalam peningkatan tegangan keluaran dari solar panel. Penelitian ini juga bertujuan untuk mengamati pengaruh jumlah modul TEG yang digunakan terhadap besarnya tegangan total TEG yang dihasilkan. Penelitian dilakukan dengan memasang beberapa modul TEG pada bagian bawah modul panel surya. Tujuh modul TEG disusun secara seri. Tegangan yang dihasilkan oleh panel surya diperoleh dari energi cahaya matahari (radiasi), sedangkan tegangan dari TEG diperoleh dari energi panas matahari. Penggabungan tegangan yang dihasilkan dari solar panel dan tegangan dari TEG disebut sebagai tegangan sistem hybrid solar energy. Dari pengujian yang dilakukan diperoleh tegangan sistem hybrid lebih besar daripada tegangan panel surya, baik dengan 6 TEG maupun dengan 7 TEG. Pada pemanfaatan 6 TEG, terdapat penambahan tegangan, yaitu rata-rata sebesar 0,60 Volt, sedangkan dengan pemanfaatan 7 TEG rata-rata sebesar 0,77 Volt.
\end{abstract}

Kata kunci : panel surya; generator elektrik; sistem hybrid

\section{PENDAhUluan}

Energi matahari merupakan sumber energi yang mudah diperoleh. Karena itu, energi matahari tergolong sebagai sumber energi terbarukan atau energi alternatif dari sumber energi fosil. Energi matahari yang sering pula disebut sebagai energi surya mengandung dua jenis energi, yaitu energi cahaya (radiasi) dan energi panas (termal) [1].

Pemanfaatan cahaya matahari sebagai sumber energi listrik dilakukan dengan menggunakan solar sel atau panel surya. Panel surya dapat dimanfaatkan untuk mengkonversi radiasi matahari menjadi energi listrik. Tegangan listrik yang dihasilkan oleh panel surya dapat dipakai untuk mengisi baterai [1].

Potensi energi panas matahari juga dapat dimanfaatkan menjadi energi listrik dengan menggunakan Thermoelectric Generator (TEG). TEG dapat memanfaatkan perbedaan suhu yang terdapat pada dua sisi benda yang berbeda suhunya untuk dikonversi menjadi beda potensial (tegangan listrik) [2].

Penggabungan energy listrik dari pemanfaatan radiasi matahari oleh panel surya dan pemanfaatan panas matahari oleh TEG sangat menarik untuk menjadi bahan penelitian. Salah satu diantaranya adalah penelitian yang berjudul "Pengembangan Hybrid Solar Cell dan Thermoelectric Generator." Pada penelitian tersebut daya yang dihasilkan dengan penambahan TEG pada sel surya lebih besar 
dibandingkan dengan daya sel surya tanpa TEG. Pada penelitiannya, Nurulianthy menggunakan 4 modul TEG [3].

Rancang bangun pembangkit listrik tenaga hybrid antara solar cell dan thermoelectric generator (TEG) sebagai sumber energi listrik di kapal nelayan juga telah dilakukan. Pada penelitian tersebut menggunakan solar cell dengan kapasitas $20 \mathrm{Wp}$ dengan jenis polycrystalline. Air panas hasil pembuangan dari proses pendinginan mesin kapal dijadikan sebagai sumbu suhu tinggi TEG dan air laut dapat dijadikan sebagai sumbu suhu rendahnya [4].

Penelitian tentang pemanfaatan TEG pada panel surya penulis lanjutkan dari kedua penelitian di atas. Perpaduan sumber energy matahari (solar), berupa radiasi/cahaya dan panas, dalam menghasilkan listrik menjadikannya tepat disebut sebagai hybrid solar energy. Pada penelitian ini, penulis menggunakan delapan modul TEG.

\section{METODE PENELITIAN}

\section{A. Pembuatan Alat}

Penelitian ini diawali dengan membuat perangkat panel surya dengan kapasitas $50 \mathrm{Wp}$. Bagian atas alat adalah tempat meletakkan modul panel surya. Bagian bawah dari panel digunakan untuk meletakkan modul TEG. Modul TEG diletakkan tepat di bagian bawah modul panel surya dengan tujuan untuk mendapatkan sumbu sisi panas TEG dari panel surya itu sendiri.
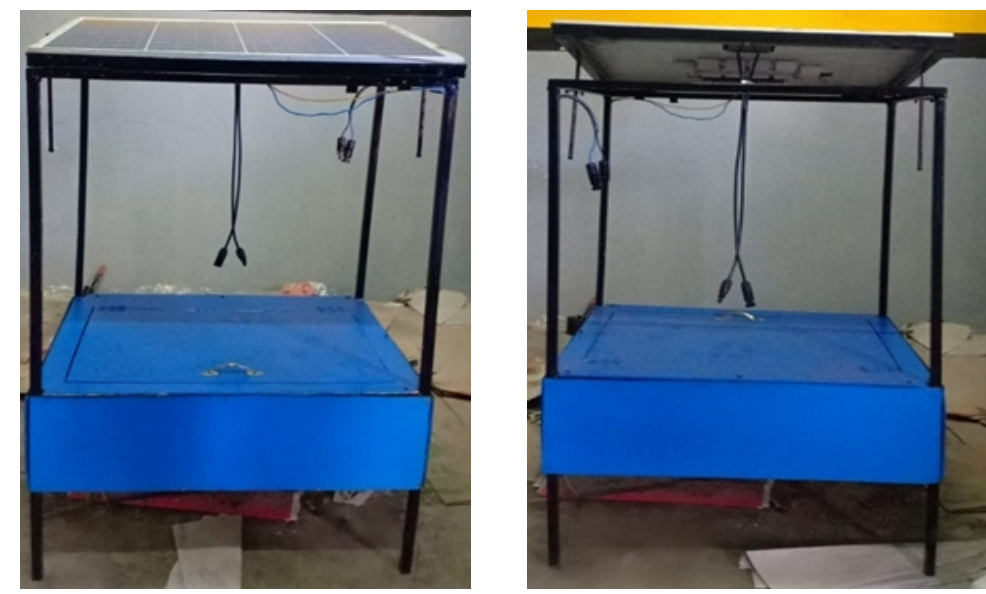

Gambar 1. Alat hybrid Solar Energy; (a) tampak depan, (b) tampak belakang

Modul Thermoelectric Generator (TEG) yang digunakan dalam penelitian ini disusun secara seri seperti pada gambar 2 .

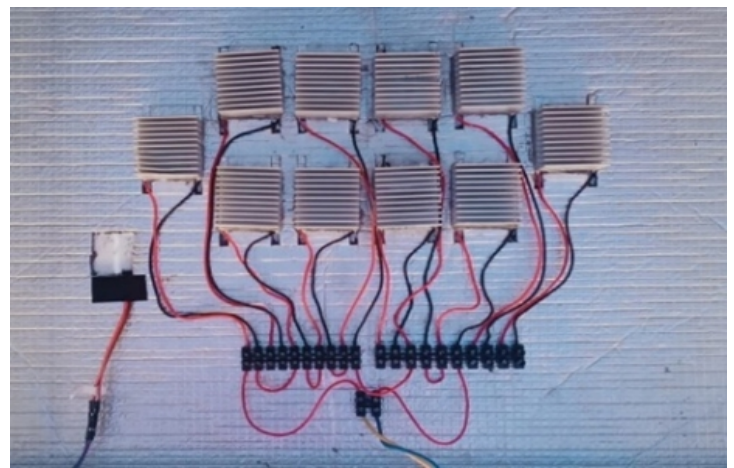

Gambar 2. Susunan modul TEG 
Gambar 2 menunjukkan susunan Thermoelectric Generator (TEG) yang dirangkai seri. Pada sistem hybrid ini, digunakan 7 TEG yang diletakkan di antara busa aluminium foil .Tujuannya adalah untuk memfokuskan suhu panas pada bagian bawah panel ke TEG, sehingga panas yang didapatkan bisa optimal. Untuk bagian dingin TEG digunakan heatsink yang bertujuan untuk menyerap panas kemudian dipindahkan ke fluida di sekitarnya.

Adapun prosedur pemasangan instalasi alat hybrid solar energy adalah sebagai berikut :

1. pemasangan panel sel surya pada rangka;

2. pemasangan rangkaian TEG secara seri;

3. peletakan rangkaian TEG di bawah panel sel surya diiringi dengan peletakan heatsink;

4. pemasangan sistem kontrol.

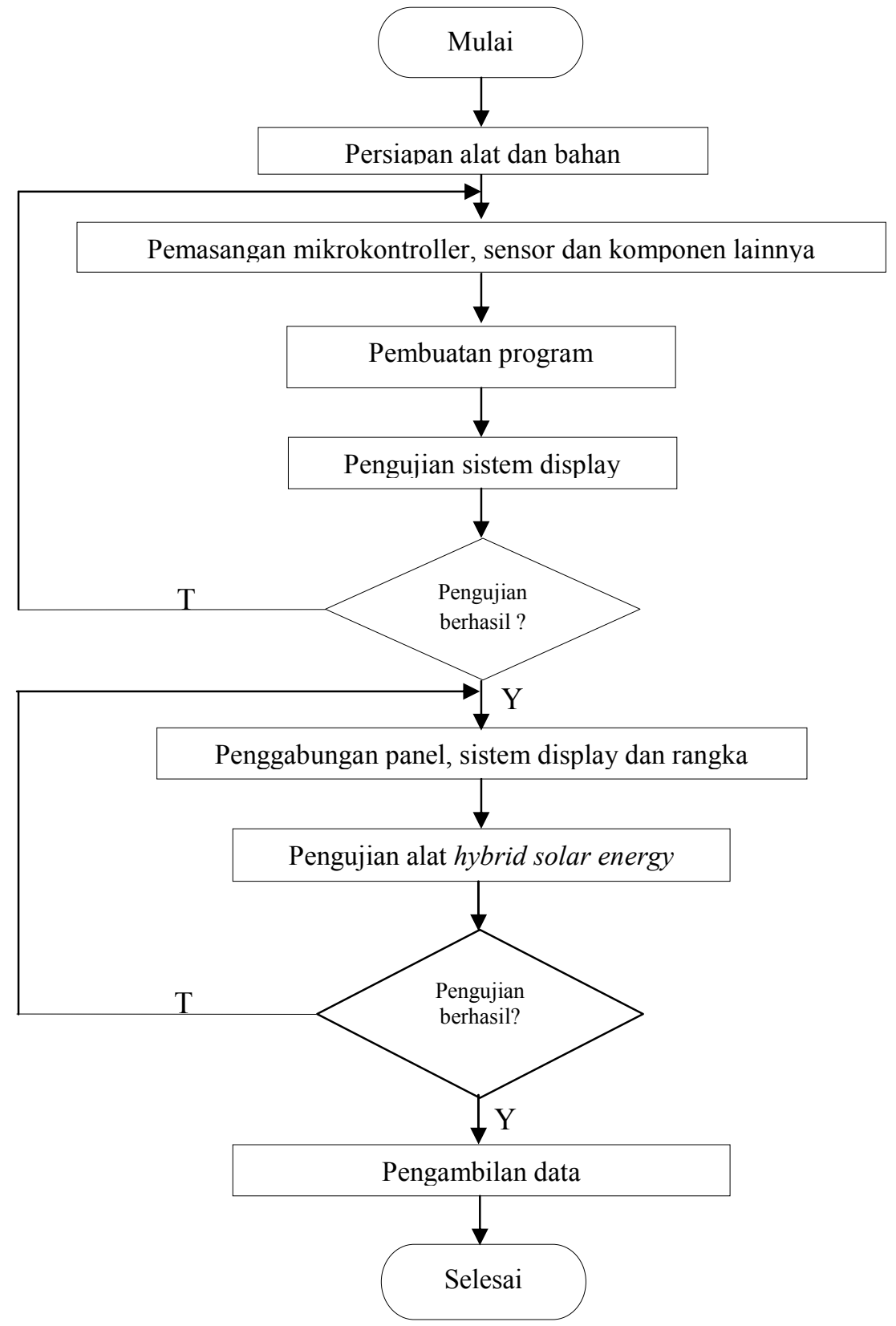

Gambar 3. Flowchart proses penelitian 


\section{B. Prosedur Pengujian}

Setelah pembuatan alat dan pemasangan instalasinya, proses selanjutnya adalah pengujian alat dan pengambilan data hasil pengujian. Berikut langkah-langkah dalam proses pengujian:

1. mengarahkan panel surya pada arah datngnya sinar matahari;

2. mengaktifkan sistem kontrol untuk mengukur parameter-parameter keluaran (output) pada alat;

4. mengukur intensitas cahaya matahari menggunakan Solar power meter TM-206 per 10 menit;

5. melakukan pengukuran temperatur panel surya, temperature suhu dingin TEG, tegangan panel surya, serta tegangan TEG;

6. melakukan pengujian selama 6 jam mulai pukul 9.00 sampai dengan pukul 15.00;

\section{HASIL DAN PEMBAHASAN}

Data hasil pengujian diperoleh dengan melakukan pengukuran besaran-besaran yang diperlukan dalam penelitian ini, mencakup:

- Intensitas Cahaya Matahari

- Tegangan Panel Surya

- Tegangan TEG

- Tegangan Hybrid

- Kuat Arus Panel Surya

- Kuat Arus TEG

- Temperatur TEG sisi tinggi

- Temperatur TEG sisi rendah

Pengujian dibagi menjadi dua bagian, yaitu:

a. Pengujian TEG

b. Pengujian system hybrid solar energy

Tabel 1. Pengujian temperatur sisi tinggi dan suhu rendah 7 TEG

\begin{tabular}{|c|c|c|c|c|c|c|c|c|c|}
\hline \multirow{2}{*}{ No. } & \multirow{2}{*}{$\begin{array}{l}\text { Waktu } \\
(\text { Wita })\end{array}$} & \multicolumn{9}{|c|}{$\begin{array}{c}\text { Sisi } \\
\text { Tinggi }\end{array}$} & \multicolumn{7}{|c|}{ Temperatur TEG $\left({ }^{\circ} \mathrm{C}\right)$} \\
\hline & & TEG-1 & TEG-2 & TEG-3 & TEG-4 & TEG-5 & TEG-6 & TEG-7 \\
\hline 1 & 09.10 & 40,2 & 38 & 37,1 & 38,4 & 36,9 & 38,1 & 37.2 & 38.3 \\
\hline 2 & 09.20 & 40,5 & 39,2 & 39,1 & 40,3 & 38,4 & 39,9 & 39,2 & 39,6 \\
\hline 3 & 09.30 & 41,6 & 40,8 & 40,2 & 40,6 & 40,5 & 40,3 & 39,7 & 39,9 \\
\hline 4 & 09.40 & 42,7 & 41,2 & 40,9 & 40,8 & 40,8 & 40,6 & 39,9 & 40,2 \\
\hline 5 & 09.50 & 42,9 & 41,8 & 41,1 & 41,3 & 41,5 & 42,9 & 40,3 & 40,5 \\
\hline 6 & 10.00 & 43,1 & 41,7 & 41 & 41,2 & 42,4 & 43 & 40,2 & 40,3 \\
\hline 7 & 10.10 & 43,8 & 40 & 42,3 & 41,5 & 42,8 & 43 & 40,1 & 40,7 \\
\hline 8 & 10.20 & 43,5 & 41,8 & 42,7 & 41,9 & 43,6 & 39,1 & 40,5 & 40,9 \\
\hline 9 & 10.30 & 45,2 & 41,9 & 43,2 & 42,8 & 43,9 & 40,3 & 42,3 & 41,4 \\
\hline 10 & 10.40 & 45,9 & 42,6 & 44,7 & 43,8 & 44,7 & 44,3 & 41,8 & 42,9 \\
\hline 11 & 10.50 & 46,3 & 42,4 & 41,9 & 45,2 & 45,8 & 45,2 & 41,6 & 47,4 \\
\hline 12 & 11.00 & 46,6 & 44,7 & 43,4 & 47,4 & 45,3 & 43,2 & 44,4 & 48,7 \\
\hline
\end{tabular}

Pada tabel 1 dapat dilihat bahwa suhu cenderung meningkat sesuai dengan perubahan waktu pengambilan data yang dilakukan. Peningkatan nilai suhu terjadi, baik pada sisi tinggi maupun pada 
sisi rendah TEG, sehingga selisih suhunya cenderung konstan. Rata-rata selisih suhu pada sisi tinggi dan sisi rendah adalah $2,03^{\circ} \mathrm{C}$. Selisih suhu terbesar adalah $4,9^{\circ} \mathrm{C}$. Kecenderungan selisih suhu yang konstan disebabkan oleh pengaruh heatsink yang digunakan. Heatsink merupakan alat penukar kalor yang menyerap panas dari suatu komponen elektronika, panas tersebut kemudian merambat menuju sirip (fin) untuk ditransfer ke lingkungan sekitar [5]. Suhu pada heatsink juga akan dipengaruhi oleh suhu dari panel surya karena terjadi proses perpindahan panas/kalor pada kedua materi tersebut. Hal ini sesuai dengan yang dikemukakan oleh Rokhimi, dkk (2015) bahwa perpindahan panas dapat di defisikan sebagai perpindahan energi dari satu daerah ke daerah lainnya sebagai akibat dari beda suhu antara daerah-daerah tersebut [6].

Tabel 2. Pengujian tegangan output 7 TEG

\begin{tabular}{|c|c|c|c|c|c|c|c|c|}
\hline \multirow{2}{*}{ No. } & \multirow{2}{*}{$\begin{array}{l}\text { Waktu } \\
(\text { Wita }\end{array}$} & \multicolumn{7}{|c|}{ Tegangan (V) } \\
\cline { 3 - 10 } & & TEG-1 & TEG-2 & TEG-3 & TEG-4 & TEG-5 & TEG-6 & TEG-7 \\
\hline 1 & 09.10 & 0,056 & 0,051 & 0,057 & 0,072 & 0,056 & 0,065 & 0,052 \\
\hline 2 & 09.20 & 0,054 & 0,087 & 0,073 & 0,091 & 0,078 & 0,086 & 0,063 \\
\hline 3 & 09.30 & 0,059 & 0,098 & 0,071 & 0,093 & 0,081 & 0,085 & 0,069 \\
\hline 4 & 09.40 & 0,062 & 0,103 & 0,076 & 0,097 & 0,083 & 0,092 & 0,073 \\
\hline 5 & 09.50 & 0,066 & 0,104 & 0,076 & 0,097 & 0,091 & 0,109 & 0,074 \\
\hline 6 & 10.00 & 0,071 & 0,112 & 0,082 & 0,101 & 0,105 & 0,116 & 0,087 \\
\hline 7 & 10.10 & 0,068 & 0,125 & 0,082 & 0,096 & 0,119 & 0,124 & 0,098 \\
\hline 8 & 10.20 & 0,072 & 0,123 & 0,078 & 0,111 & 0,093 & 0,105 & 0,079 \\
\hline 9 & 10.30 & 0,076 & 0,142 & 0,088 & 0,125 & 0,104 & 0,134 & 0,083 \\
\hline 10 & 10.40 & 0,079 & 0,139 & 0,094 & 0,121 & 0,097 & 0,128 & 0,089 \\
\hline 11 & 10.50 & 0,078 & 0,149 & 0,099 & 0,125 & 0,089 & 0,111 & 0,092 \\
\hline 12 & 11.00 & 0,082 & 0,126 & 0,098 & 0,123 & 0,096 & 0,117 & 0,095 \\
\hline
\end{tabular}

Pada tabel 2 dapat dilihat bahwa ketujuh Thermoelectric Generator (TEG) yang digunakan dapat menghasilkan output berupa tegangan dalam orde $\mathrm{mV}$. Hal tersebut sesuai dengan prinsip kerja TEG yang berdasarkan efek seebeck, yaitu jika dua buah logam yang berbeda disambungkan salah satu ujungnya, kemudian diberikan suhu yang berbeda pada sambungan, maka terjadi perbedaan tegangan pada ujung yang satu dengan ujung yang lain [7]. Tegangan yang dihasilkan oleh ketujuh TEG tersebut bervariasi, berkisar antara 0,051 V sampai dengan $0,149 \mathrm{~V}$. Tegangan output rata-rata ketujuh TEG dengan 12 sampel pengambilan data adalah $0,092 \mathrm{~V}$.

Pengujian pada sistem perpaduan antara solar panel dengan TEG (system hybrid solar energy) dibagi menjadi 2 kategori data, yaitu:

- $\quad$ dengan menggunakan 6 TEG dihubung seri

- $\quad$ dengan menggunakan 7 TEG dihubung seri

Pengambilan data hasil pengujian dilakukan tiap 10 menit, dari pkl. 09.10 hingga pukul 15.00 Wita. 
Tabel 3. Pengujian output sistem hybrid dengan 6 TEG dihubung seri

\begin{tabular}{|c|c|c|c|c|c|c|}
\hline \multirow{2}{*}{ No. } & \multirow{2}{*}{$\begin{array}{l}\text { Waktu } \\
\text { (Wita) }\end{array}$} & \multirow{2}{*}{$\begin{array}{c}\text { Intensitas } \\
\text { Matahari }\left(\mathrm{W} / \mathrm{m}^{2}\right)\end{array}$} & \multirow{2}{*}{$\begin{array}{c}\triangle \mathrm{T}-\mathrm{TEG} \\
\left({ }^{\circ} \mathrm{C}\right)\end{array}$} & \multicolumn{3}{|c|}{ Tegangan (Volt) } \\
\hline & & & & Panel & TEG & Hybrid \\
\hline 1 & 9.10 & 733,9 & 2,8 & 19,56 & 0,479 & 20,44 \\
\hline 2 & 9.20 & 806,1 & 2,7 & 19,75 & 0,567 & 20,32 \\
\hline 3 & 9.30 & 808,4 & 3,1 & 19,58 & 0,529 & 20,12 \\
\hline 4 & 9.40 & 931,8 & 2,9 & 19,59 & 0,554 & 20,18 \\
\hline 5 & 9.50 & 1004,6 & 3,4 & 19,48 & 0,631 & 20,05 \\
\hline 6 & 10.00 & 1001,2 & 3,1 & 18,5 & 0,61 & 20,11 \\
\hline 7 & 10.10 & 1022,6 & 2,7 & 19,46 & 0,642 & 20,13 \\
\hline 8 & 10.20 & 1046,9 & 3,9 & 19,47 & 0,638 & 20,32 \\
\hline 9 & 10.30 & 1089,7 & 4,3 & 19,36 & 0,602 & 19,99 \\
\hline 10 & 10.40 & 1103,3 & 4,6 & 19,26 & 0,629 & 19,91 \\
\hline 11 & 10.50 & 1112,3 & 4,1 & 19,14 & 0,629 & 19,79 \\
\hline 12 & 11.00 & 1099,6 & 5,3 & 19,14 & 0,652 & 19,81 \\
\hline 13 & 11.10 & 1156,5 & 5,8 & 19,4 & 0,745 & 20,11 \\
\hline 14 & 11.20 & 1248,5 & 4,8 & 19,49 & 0,815 & 20,31 \\
\hline 15 & 11.30 & 1268,8 & 5,1 & 19,26 & 0,808 & 20,05 \\
\hline 16 & 11.40 & 1215,5 & 5,4 & 19,37 & 0,455 & 19,73 \\
\hline 17 & 11.50 & 1237,2 & 5,2 & 19,43 & 0,625 & 19,99 \\
\hline 18 & 12.00 & 1264,9 & 5,7 & 19,62 & 0,712 & 20,26 \\
\hline 19 & 12.10 & 1234,1 & 6,2 & 19,56 & 0,549 & 19,98 \\
\hline 20 & 12.20 & 1243,7 & 6,5 & 19,54 & 0,521 & 19,85 \\
\hline 21 & 12.30 & 1251,3 & 6,9 & 19,57 & 0,513 & 19,83 \\
\hline 22 & 12.40 & 1249,7 & 7,2 & 19,52 & 0,519 & 19,92 \\
\hline 23 & 12.50 & 1205,6 & 6,5 & 19,48 & 0,546 & 19,91 \\
\hline 24 & 13.00 & 1226,8 & 6,9 & 19,53 & 0,515 & 20 \\
\hline 25 & 13.10 & 1188,5 & 6,6 & 19,51 & 0,543 & 20,02 \\
\hline 26 & 13.20 & 1220,5 & 6,3 & 19,47 & 0,655 & 20,13 \\
\hline 27 & 13.30 & 1150,8 & 5,9 & 19,5 & 0,411 & 19,77 \\
\hline 28 & 13.40 & 1170,9 & 5,4 & 19,58 & 0,645 & 20,18 \\
\hline 29 & 13.50 & 1130,7 & 5,1 & 19,51 & 0,705 & 20,21 \\
\hline 30 & 14.00 & 1060,4 & 4,7 & 19,52 & 0,605 & 20,12 \\
\hline 31 & 14.10 & 1077 & 4,3 & 19,61 & 0,659 & 20,26 \\
\hline 32 & 14.20 & 1001,2 & 4,8 & 19,68 & 0,609 & 20,28 \\
\hline 33 & 14.30 & 939,5 & 4,3 & 19,64 & 0,527 & 20,17 \\
\hline 34 & 14.40 & 930,5 & 3,4 & 19,64 & 0,525 & 20,16 \\
\hline 35 & 14.50 & 939,8 & 3,7 & 19,77 & 0,599 & 20,45 \\
\hline 36 & 15.00 & 860,6 & 2,3 & 19,83 & 0,529 & 20,45 \\
\hline
\end{tabular}


96 Sukma Abadi, Makmur Saini, Andar Triwijaya, Fina Pratiwi. Pemanfaatan Thermoelectric Generator pada Pembangkit Listrik Tenaga Surya (PLTS)

Tabel 4. Pengujian output sistem hybrid dengan 7 TEG dihubung seri

\begin{tabular}{|c|c|c|c|c|c|c|}
\hline \multirow{2}{*}{ No. } & \multirow{2}{*}{$\begin{array}{l}\text { Waktu } \\
\text { (Wita) }\end{array}$} & \multirow{2}{*}{$\begin{array}{c}\text { Intensitas } \\
\text { Matahari }\left(\mathrm{W} / \mathrm{m}^{2}\right)\end{array}$} & \multirow{2}{*}{$\begin{array}{l}\Delta \mathrm{T}-\mathrm{TEG} \\
\left({ }^{\circ} \mathrm{C}\right)\end{array}$} & \multicolumn{3}{|c|}{ Tegangan (Volt) } \\
\hline & & & & Panel & TEG & Hybrid \\
\hline 1 & 9.10 & 732,1 & 2,3 & 19,68 & 0,521 & 20,34 \\
\hline 2 & 9.20 & 777,3 & 2,6 & 19,85 & 0,596 & 20,46 \\
\hline 3 & 9.30 & 837,3 & 3,1 & 19,71 & 0,599 & 20,31 \\
\hline 4 & 9.40 & 855,5 & 3,5 & 19,67 & 0,657 & 20,29 \\
\hline 5 & 9.50 & 880,8 & 3,6 & 19,76 & 0,698 & 20,46 \\
\hline 6 & 10.00 & 906,1 & 3,7 & 19,74 & 0,681 & 20,44 \\
\hline 7 & 10.10 & 993,1 & 4,2 & 19,65 & 0,711 & 20,35 \\
\hline 8 & 10.20 & 1083,3 & 4,8 & 19,65 & 0,825 & 20,52 \\
\hline 9 & 10.30 & 1132,5 & 4,6 & 19,72 & 0,785 & 20,51 \\
\hline 10 & 10.40 & 1167,6 & 5,3 & 19,56 & 0,898 & 20,52 \\
\hline 11 & 10.50 & 1125,9 & 4,7 & 19,61 & 0,843 & 20,48 \\
\hline 12 & 11.00 & 1125,5 & 4,9 & 19,56 & 0,855 & 20,43 \\
\hline 13 & 11.10 & 1167,3 & 4,8 & 19,45 & 0,798 & 20,25 \\
\hline 14 & 11.20 & 1128,9 & 5,6 & 19,45 & 0,876 & 20,26 \\
\hline 15 & 11.30 & 1158,3 & 5,9 & 19,49 & 0,851 & 20,35 \\
\hline 16 & 11.40 & 1162,8 & 6,4 & 19,4 & 0,864 & 20,25 \\
\hline 17 & 11.50 & 1159 & 6,2 & 19,51 & 0,872 & 20,42 \\
\hline 18 & 12.00 & 1183,4 & 6,7 & 19,42 & 0,877 & 20,32 \\
\hline 19 & 12.10 & 1158,2 & 6,8 & 19,36 & 0,875 & 20,26 \\
\hline 20 & 12.20 & 1223 & 7,3 & 19,41 & 0,837 & 20,25 \\
\hline 21 & 12.30 & 1218,7 & 7,7 & 19,43 & 0,894 & 20,32 \\
\hline 22 & 12.40 & 1214,7 & 8,1 & 19,46 & 0,896 & 20,44 \\
\hline 23 & 12.50 & 1204,4 & 7,6 & 19,36 & 0,779 & 20,14 \\
\hline 24 & 13.00 & 1107,2 & 7,2 & 19,38 & 0,882 & 20,25 \\
\hline 25 & 13.10 & 1199,3 & 7,1 & 19,55 & 0,877 & 20,45 \\
\hline 26 & 13.20 & 1169,3 & 6,5 & 19,51 & 0,796 & 20,32 \\
\hline 27 & 13.30 & 1199,1 & 7,2 & 19,73 & 0,861 & 20,59 \\
\hline 28 & 13.40 & 1089,4 & 6,9 & 19,78 & 0,816 & 20,61 \\
\hline 29 & 13.50 & 1040,1 & 6,2 & 19,62 & 0,733 & 20,36 \\
\hline 30 & 14.00 & 1023,3 & 6,3 & 19,69 & 0,761 & 20,49 \\
\hline 31 & 14.10 & 953,2 & 5,7 & 19,77 & 0,691 & 20,48 \\
\hline 32 & 14.20 & 946,9 & 5,3 & 19,8 & 0,692 & 20,55 \\
\hline 33 & 14.30 & 921,6 & 4,6 & 19,83 & 0,641 & 20,46 \\
\hline 34 & 14.40 & 842,3 & 3,9 & 19,82 & 0,596 & 20,38 \\
\hline 35 & 14.50 & 767,6 & 3,2 & 19,88 & 0,593 & 20,48 \\
\hline 36 & 15.00 & 761,4 & 2,7 & 19,96 & 0,569 & 20,53 \\
\hline
\end{tabular}


Pada tabel 3 data hasil pengujian tegangan keluaran sistem hybrid solar energy dapat dilihat bahwa tegangan keluaran sistem lebih besar daripada tegangan yang dihasilkan oleh panel surya. Pada pemanfaatan 6 TEG, terdapat penambahan tegangan, yaitu rata-rata sebesar 0,60 Volt, sedangkan dengan pemanfaatan 7 TEG rata-rata sebesar 0,77 Volt. Besarnya tegangan yang diberikan oleh masing-masing TEG pada sistem bersifat variatif, namun cenderung mengikuti fluktuasi perubahan nilai radiasi matahari. Hal ini dapat diperjelas melalui gambar 43 berikut:

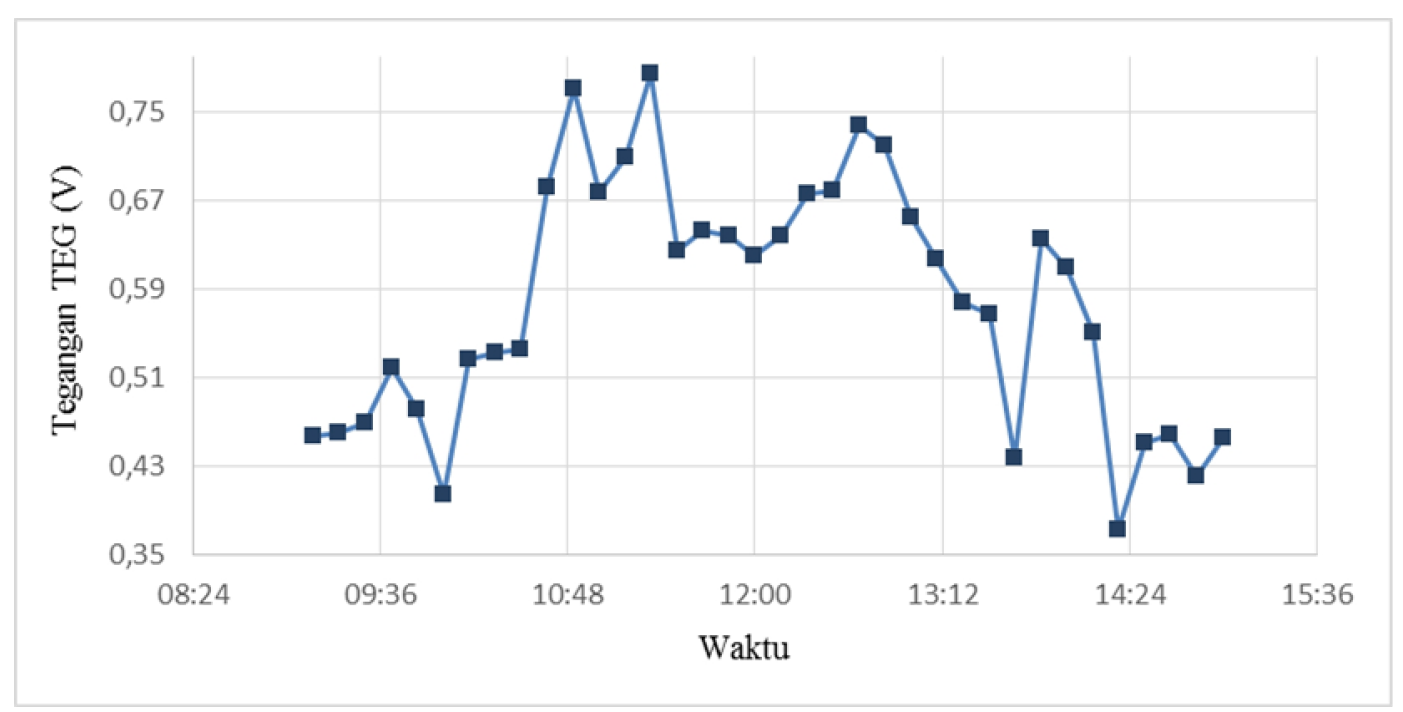

Gambar 4. Variasi nilai tegangan TEG berdasarkan Waktu

\section{KESIMPULAN}

Berdasarkan hasil dan pembahasan dapat disimpulkan:

a. Panas yang dibawa serta oleh radiasi matahari pada panel surya dapat dimanfaatkan untuk menghasilkan tegangan yang lebih besar daripada tegangan yang dihasilkan oleh panel surya melalui pemanfaatan Thermoelectric Generator (TEG). Tegangan output dari penggabungan tegangan panel surya dan tegangan TEG dapat menghasilkan tegangan hybrid rata-rata sebesar 0,60 Volt (dengan 6 TEG) dan 0,77 Volt (dengan 7 TEG).

b. Untuk menghasilkan tegangan total dari penggunaan beberapa TEG dalam sistem hybrid solar energy, maka TEG harus disusun secara seri. Dengan demikian, semakin banyak modul TEG yang disusun seri, maka tegangan total yang dihasilkan juga akan semakin besar.

c. Secara umum, tegangan yang dihasilkan oleh TEG bervariasi dan tidak menunjukkan trend tertentu, baik naik maupun turun. Namun demikian, besarnya tegangan TEG cenderung mengikuti besarnya radiasi cahaya matahari yang berbanding lurus dengan panas yang dibawanya.

\section{DAFTAR PUSTAKA}

[1] Kreith, Frank dan Arko Prijono M.Sc. 1997. Prinsip-Prinsip Perpindahan Panas edisi Ketiga. Jakarta: Penerbit Erlangga.

[2] Yunianto, Bambang. 2010. Pengujian Perpindahan Panas Konveksi pada Heatsink Plat Jenis Extrude dan Heatsink Plat dengan Slot. Seminar Nasional Tahunan Teknik Mesin ke-9, Palembang Oktober 2010.

[3] Nurulianthy, Annisa. 2012. Pengembangan Hybrid Solar Cell dengan Thermoelectric Generator. Skripsi. Fakultas Teknik. Universitas Indonesia. 
98 Sukma Abadi, Makmur Saini, Andar Triwijaya, Fina Pratiwi. Pemanfaatan Thermoelectric Generator pada Pembangkit Listrik Tenaga Surya (PLTS)

[4] Argianto, Riengga Agus dan Istiyo Winarno. 2017. Rancang Bangun Pembangkit Listrik Tenaga Hybrid antara Solar Cell dan Termoelecric Generator (TEG) sebagai Sumber Energi Listrik Di Kapal Nelayan. Laporan Tugas akhir Fakulas Teknik dan Ilmu Kelautan Universitas Hang Tuah Surabaya.

[5] Muchmmmad. 2007. Analisa Pressure Drop Pada Heat-Sink Jenis Large Extrude Dengan Variasi Kecepatan Udara Dan Lebar Saluran Impingement Menggunakan Cfd (Computational Fluid Dynamic). ROTASI - Volume 9 Nomor 2 April 2007 hal. 31.

[6] Rokhimi, Intan Nurul dan Pujianto. 2015. Alat Peraga Pembelajaran Laju Hantaran Kalor Konduksi. Prosiding Seminar Nasional Fisika dan Pendidikan Fisika (SNFPF) Ke-6 2015270 Volume 6 Nomor 12015 ISSN :2302-7827.

[7] Muhaimin. 1993. Bahan-bahan listrik untuk Politeknik. Jakarta : Pradya Paramitha. 